\title{
5. Four or fewer freedoms: justice contested and codified between 1941 and 1957
}

\author{
Barbara Oomen and Alexandra Timmer
}

\subsection{INTRODUCTION}

A key aspect of investigating the foundations of justice in Europe is to understand how these developed over time. Such an inquiry can begin in many different places and at many different moments. This chapter, however, focuses on the period during and after the Second World War, from 1941 to 1957. One reason for this is that the Second World War was, in many different ways, the reason for closer cooperation within Europe and for the institutionalization of such cooperation. Another is the degree to which this particular period was still characterized by an openness and indefiniteness in terms of the type of justice to be institutionalized in Europe. By the time of the formation of the European Economic Community (EEC) in 1957 this was very different - clear choices had been made in terms of the type of justice institutionalized in the European project. A close consideration of the particular debates that led to these institutional outcomes, of the people involved and the ideas that they held can offer important insight into the conceptions of justice on and off the table in this early period of European formation (Norman and Zaidi 2008).

As set out in the introduction to this book, justice as a concept and an overarching ideal is - surprisingly - not often discussed amongst those studying Europe, most notably not amongst lawyers and others studying European institutions. It could well be that the notion of justice is simply too big, or too abstract to engage with. Recent scholarship, however, has lamented Europe's justice deficit, explicitly calling for a systematic inquiry on the interrelationship between law and justice in the European project (Kochenov et al. 2015). Williams, to quote an example, speaks of the 'uncertain soul' of Europe: 'People simply do not know what the EU stands for' (Williams 2010, p. 9). Ward, another scholar concerned about the lack of engagement with larger questions of justice in Europe today, quotes Vaclav Havel in stating that 
'Europe today lacks an ethos, it lacks imagination' (Ward 2003, p. 257). In response to this, we seek to understand how Europe was imagined at a very formative moment, thus connecting bodies of literature that all shed light on justice in Europe, which are so far surprisingly disconnected: the literature on transatlantic dialogues (Borgwardt 2007), on European human rights law (Duranti 2016) and on the history of the European Union (Dinan 2004).

We take the Four Freedoms Speech of the American President Franklin Delano Roosevelt (FDR) in 1941 as a point of departure. This is for two reasons. One is that that these Four Freedoms provided a first glimpse of a number of essential features of post-war institutionalization of justice in Europe, most notably its combination of emphasis on individual freedoms, an obligation towards multilateral cooperation to protect them, and some form of supranational supervision of their enforcement. Roosevelt, in his speech, not only set out what the war was against, but also what it was for. In contrast to earlier attempts to stimulate multilateral cooperation with international law as its main fabric, such as the Hague Peace Conference and the interbellum experiments largely led by Woodrow Wilson, the speech envisaged an international community to safeguard individual rights. As such, this period could be considered a 'Grotian moment', a paradigm shift in international law that transformed internationalization and crystalized conceptions of justice in an unprecedented manner (Scharf 2010).

The formulation of the Four Freedoms marked the beginning of a series of foundational moments, in which certain conceptions of justice were tabled, ignored or enthusiastically embraced as Europe crawled out of war to take its current institutional shape. The malleable character of this institutional shape also means that the 'Europe' referred to here had different forms over time - from an ideal with supporters in nations all over the European continent, to the institutionalized Europe in the context of the Congress of Europe, the European Coal and Steel Community and the EEC (Chakrabarty 2009).

In order to analyse which justice conceptions dominated and which ones were ignored, this chapter focuses on a number of key moments, personalities and processes that led to the transformation of one justice ideal into a notably different one. Each codification of justice, after all, is 'propelled by individuals, and individuals are still inspired to positive action by ideas' (Borgwardt 2007, p. 298). Out of all the important moments in the formulation, negotiation, contestation and institutionalization of particular conceptions of justice, some of the most important were the drawing up of the Atlantic Charter, the founding of the United Nations and the drawing up of the Universal Declaration of Human Rights (UDHR), the Congress of Europe, the founding of the Council of Europe, and the run-up to the EEC. After a discussion of these marking moments, we outline which conceptions of justice conquered, which would remain contested and which were more or less circumvented in 
this foundational period. The conclusion, finally, considers the degree to which the post-war codification of particular justice ideals and the neglect of others still casts its shadow over Europe today.

\subsection{TRANSATLANTIC FOUNDATIONS}

\subsubsection{FDR's Four Freedoms and the Atlantic Charter}

The tale of the conceptions of justice that gained prominence during and after wartime Europe thus starts, perhaps surprisingly, in Washington in January 1941. In his State of the Union address that would be recognized as one of the most important speeches ever, FDR not only advocated American involvement in the war but also emphasized how the war threatened the American way of life, and sketched his vision of the world order in future days, 'which we seek to make secure' (Engel 2016). These days needed a moral order, based on the 'cooperation of free countries, working together in a free, civilized society' (Roosevelt 1941). This world order would be founded on four fundamental freedoms: the freedom of speech and expression, the freedom of worship, the freedom from want (as a means to internationalize the New Deal) and the freedom from fear, 'everywhere in the world' (Ead 2016).

FDR's 'doable plan' (Roosevelt 1951) for peace and the vision of justice underpinning the Four Freedoms speech can be summarized as combining liberty rights, social justice and security for everyone in the world, made possible by a world order based on cooperation. The connection of these ideals with the future of Europe would take place seven months later, on a ship on the Atlantic, when Roosevelt and Churchill wrote the Atlantic Charter. This eight-point statement contained provisions on peace, called for the abandonment of the use of force and against aggrandisement. It also emphasized, as a common principle, the respect for 'the right of all peoples to choose the form of Government under which they will live' (Atlantic Charter, 1941, p. 2). In addition, the leaders expressed commitment to doing away with trade barriers, in order to secure 'for all improved labour standards, economic advancement, and social security' (Atlantic Charter, 1941, p. 2). Where it concerned the means to realize this, Churchill had proposed 'an effective international organization' to keep such peace, but found the provision struck out by FDR who feared a lack of domestic support (Borgwardt 2007).

Just as Roosevelt had added the words 'everywhere in the world' in the Four Freedoms speech, in handwriting, at the very last moment, here too a small sentence scribbled down last-minute by a statesman - inadvertently - contained the seeds for a future revolution in the field of justice. It was Churchill who, most probably for poetic effect, added 'all the men in all the lands' to the statement that called for a peace in which 'all the men in all the lands may live 
out their lives in freedom from fear and want' (Borgwardt 2007, p. 20). The underlying message of universal rights was, however, not lost on those colonized by the British, such as the young lawyer Nelson Mandela (Borgwardt 2007). As a result, Churchill was called to the House of Commons the next month, where he explained that the Charter covered primarily 'the restoration of sovereignty, self-government and national life of the States and nations of Europe now under Nazi yoke' (Churchill 1941). Issues of self-governance for the colonies, he asserted, formed quite a separate problem. It was thus within weeks of the formulation of the Atlantic Charter that its promise was limited to those in mainland Europe, with the vast masses under European rule in the colonies exempted.

\subsubsection{The United Nations and the Universal Declaration of Human Rights}

The Atlantic Charter, in Churchill's words, was a 'milestone or monument which needs only the stroke of victory to become a permanent part of the history of human progress' (Chruchill 1941). Even if this stroke would take four more years, negotiations on the post-war order continued. One important moment came with the January 1942 'Declaration by United Nations', in which 26 countries from all over the world expressed support for the purposes and principles of the Atlantic Charter. The Declaration formulated as the purpose of victory 'to defend life, liberty, independence and religious freedom, and to preserve human rights and justice in their own lands as well as in other lands' (Borgwardt 2007, p. 55), thus marking the emergence of modern human rights law. The term 'human rights' and the reference to religious freedom were inserted at the initiative of the Americans - to the discontent of the Soviet signatories.

Yet, it was far from given that human rights would also become one of the objectives of the United Nations, to be formed in 1945. When the US, the UK, China and the USSR came together in Dumbarton Oaks in 1944, the only main aim of the post-war organization they could agree upon was that of peace. The Economic and Social Council, propagated by the US, was already problematic to the Soviets, and only the Americans were in favour of a provision on human rights (Hoopes and Brinkley 1997). It was only due to the smaller countries, and persistent non-governmental organization (NGO) lobbying (most notably by the American Jewish Committee) that the United Nations (UN) also formally purported to promote and encourage 'respect for human rights and for fundamental freedoms for all without distinction as to race, sex, language, or religion' (Korey 2001, p. 2). Another document, negotiated in San Francisco in the same month, encapsulated the same zeitgeist: the need to secure the freedom from fear of aggressive war. The Nuremberg Charter would focus 
on outlawing wars of aggression, and punishing crimes like genocide during wartime, and subsequently make its way into the Genocide Convention of 1948 (Sands 2003). The legal attention to the atrocities committed during the war, however, did not extend to the kind of attention to restorative justice that would become important by the end of the century.

The UN Charter might have referred to human rights, but their substance still had to be worked out and written into the Universal Declaration of Human Rights. This work was undertaken by a commission under the leadership of Eleanor Roosevelt and a drafting committee with French, Chinese, Chilean, Australian, Russian and Lebanese delegates (Morsink 1999; Glendon 2002). Possibly as a result of this diverse composition, the UDHR, adopted on 10 December 1948, contained an impressive range of civil and political, social and economic rights. The underlying principles were famously depicted by René Cassin as a portico with four founding principles: dignity, liberty, equality and brotherhood. Conspicuously absent, however, was the right to self-determination - a clear indication of the dominance of Western (colonial) powers in the negotiating process. The Declaration also, for the same reasons, lacked an explicit right to equal treatment - even if the Indian Hansa Mehta had successfully ensured gender-neutral language by advocating changing 'all men' into 'all human beings' in the first article (Glendon 2002, p. 289).

Although the UDHR is a relatively comprehensive document, it clearly reflects the dominance of American and Western European viewpoints. The document contains references to social and economic rights, but not to the extent and with the weight that negotiating partners like the Latin American countries and the USSR had called for (Norman and Zaidi 2008). It also emphasizes rights over responsibilities, even if Mahatma Gandhi was hardly alone in underlining that 'the very right to live accrues to us only when we do the duty of the citizenship of the world' and in arguing in favour of a statement of duties (as quoted in Maritain 1948, p. 18). Moreover, it neglected the position of minorities - another consequence of domestic American politics (Humphrey 1968). These choices would not be rectified in the institutionalization of justice in post-war Europe, as set out below.

\subsection{NEGOTIATING JUSTICE IN POST-WAR EUROPE}

While the architecture of global justice was negotiated in the context of the first UN meetings, discussions on a separate supranational organization in and for Europe gathered speed. Such discussions could build upon interbellum activities like the Pan-European movement, and on the French statesman Briand's idea of how to turn an 'idea of philosophers and poets' into a federal European bond in the context of the League of Nations (Briand 1930). They were triggered by the notion of 'nie wieder' following the devastation of the 
Second World War, but also by a fear of the emerging geo-political reality. Communism was clearly on the rise in the East, and Churchill had already set out how 'an iron curtain has descended across the continent' (Churchill 1946a). Just as the UDHR has been described as the 'last train out of the station' for the UN, so Spinelli has described what was at stake in the small window of opportunity before the Cold War set in as a 'brief, intense period of general crisis when the States will lie broken, when the masses will be anxiously waiting for a new message, like molten matter, burning, and easily shaped into new moulds' (Spinelli and Rossi 1941).

The question, of course, was into what mould the 'molten matter' would be poured. As old as the proposals of poets, philosophers and politicians for uniting Europe was the debate on the reasons for doing so. The aims of European cooperation, and the underlying perceptions of justice would be central to the negotiations to which we now turn: the Hague Congress, the formation of the Council of Europe and, finally, the stepping stones that led to the formation of the EEC.

\subsubsection{The Hague Congress: Carving the Course of Justice for Europe}

A decisive moment in casting Spinelli's mould was the Hague Congress, held from 7 to 11 May 1948 and largely organized by Winston Churchill. The former prime minister had already laid the rhetorical foundations to 'recreate the European fabric, or as much of it as we can, and to provide it with a structure under which it can dwell in peace, safety and freedom', in the 1946 Zurich speech in which he proposed the United States of Europe (Churchill 1946b). In opening the Hague Congress, Churchill set the tone by emphasizing that 'President Roosevelt spoke of the Four Freedoms, but the one that matters most today is Freedom from Fear' (Churchill 1948). The Congress was a watershed moment, not only because of 'the doors that it opened, but also because of what it turned away from' (Cohen 2009, p. 273). A large part of the explanation for the choices made in terms of justice lies in the composition of the attendees, with a strong emphasis on politics and business, and very little space for labour; for these reasons, the Congress was depicted by some as having a 'right wing bias' (Brugmans 1969, p. 24). The outcome of four days of heated negotiations was a pledge that foreshadowed the direction Europe would take. Its preamble curtly stated how:

Europe's mission is clear. It is to unite her peoples with their genius of diversity and with the conditions of modern community life, and so open the way towards organized freedom for which the world is seeking. It is to revive her inventive powers for the greater protection of the rights and duties of the individual of which, in spite of all her mistakes, Europe is still the greatest exponent. (European Movement 1949, p. 94) 
The delegates pledged their desire for a 'United Europe, throughout whose area the free movement of persons, ideas and goods is restored', thus prioritizing market freedoms and the demands of capitalism. In addition, delegates called for a 'Charter of Human Rights guaranteeing liberty of thought, assembly and expression as well as the right to form a political opposition' (European Movement 1949, p. 94). The social and economic rights still enthusiastically being debated by the delegates working on the UDHR in Paris were thus sidelined. The Economic and Social Committee passed a resolution emphasizing these rights but this did not make it to the final pledge (Loth 2015).

A third element of the pledge introduced the idea of a Court of Justice. This revived the old idea of instating a World Court in the European context, and thus strengthening the rule of law at the European level - the Court would limit the sovereignty of states in supervising their compliance with a strictly defined set of rights. The two final articles envisaged the type of democracy that Europe would be, by proposing a European Assembly. At the time, the ideal of Europe had unprecedented support among the population at large, and the Congress itself could well be considered a 'civil society achievement' (Glasius 2006, p. 111). The Congress led to the creation of the European Movement on 25 October 1948. Another, more intergovernmental outcome of the Congress was the agreement by the French, the British and the Benelux countries to set up a Council of Europe, which would be officially founded in London in May 1949 (Brugmans 1969).

\subsubsection{Working Towards a European Convention}

It was the European Movement, as a civil society organization, that took the lead in translating broad conceptions of justice for Europe into specific proposals. On 12 July 1949, the European Movement submitted a Draft Convention on Human Rights to the Committee of Ministers of the Council of Europe. This draft proved to be crucial in the evolution of European human rights law, as it provided the basis for the final text of the European Convention on Human Rights (ECHR) which would be adopted only a year later. The chief aim of the draft was to lay down the freedoms that together would guarantee peace and prevent a re-emergence of totalitarian regimes (Bates 2010). The drafters referred to the UDHR and acknowledged its importance (European Movement 1949). However, the European Movement felt that Europe needed a legally binding human rights instrument, to safeguard individual freedoms.

The text laid down individual freedoms (Article 1) and political liberties (free elections, the 'right of political criticism and the right to organize a political opposition', Article 2). Seeking to protect Western democracy was the draft's main aim (Bates 2010). Social and economic rights were not included, but Article 4 did provide that the selected rights 'shall not imply any limitation 
whatsoever of other rights not here enumerated and in particular of the rights proclaimed in the Universal Declaration of Human Rights'.

The justice conceptions that underlay this Draft Convention were deeply contested, as became clear in a 1949 publication of the European Movement. Out of the seven criticisms discussed in the publication, some sound remarkably familiar for modern readers, including the criticism that the draft only guaranteed a limited number of rights and omitted others; that the European Court of Human Rights (ECtHR) might encroach upon the jurisdiction of national courts, would be inundated with complaints, and would be exploited for political ends; and that the ECHR would involve some surrender of sovereignty (European Movement 1949). Here, too, there seemed to be a strategy of discrediting social and economic rights and making them invisible. These rights were not mentioned as such, and the only concrete right that was mentioned in the publication is the 'right to rest' (European Movement 1949, p. 120). A legal-technical argument was used - only rights that are 'practicable to enforce through the processes of a court of law' were chosen for inclusion in the Draft - thus masking what was actually a very contentious political issue, going to the very core of how justice was conceived.

When the European Movement's Draft Convention was presented at the very first session of the Consultative Assembly of the Council of Europe, held in Strasbourg in August 1949, many representatives attending the conference still believed that they were there to create some form of 'economic and political' European union as was decided at the Hague Congress (Robertson 1961; Bates 2010). The Committee of Ministers, however, rejected virtually all the recommendations that were produced concerning further European integration, save the ones concerning a Convention on Human Rights (Bates 2010). The Consultative Assembly discussed whether the Convention should only include the minimum number of rights necessary to ensure the functioning of democracy, or whether the scope of the Convention should be broader. In particular, there was debate on whether family related rights (for example, the right to family life and the right to marry), the right to education, and the right to property should be included. Bates concludes that 'the original ambitions for the Convention were very basic indeed' and that it was primarily seen as a 'collective pact against totalitarianism' (Bates 2010, p. 75).

In the period between the Consultative Assembly of the late summer of 1949 and the adoption of the ECHR and the founding of the Council of Europe in 1950 , the rights to be included were further negotiated. For one, the right to free elections was dropped from the final text, at the insistence of the British, to be included in an Optional Protocol, together with the right to own property and the right to education (Bates 2010). Against a backdrop of fierce political debate about colonialism and a fear of communism, these three rights were all the subject of much contestation. The British Colonial Office might have 
held that 'colonialism, as such, did not present human rights problems' (as quoted in Bates 2010, p. 762), but colonialism did prove an impediment to the inclusion of these rights into the main text of the ECHR. The right to property was contested because socialist governments, in particularly the UK and Sweden, were concerned that it would hinder the nationalization of private property for political and social purposes. The right of parents to choose the education of their children raised the question whether communist parents in non-communist countries had the right to have their children educated in line with Marxism and Leninism (Robertson 1961).

To make the distinction between territorial Europe and the colonies overtly clear, the final text of the Convention also included a so-called 'colonial clause' (then Article 63), which made clear that the Convention did not automatically apply to the overseas territories of the European powers. This clause had been much disputed in the Consultative Assembly. Léopold Sedar Senghor, later President of the Republic of Senegal, pleaded with the Assembly to suppress the clause: 'In adopting Article 63, the Assembly would transform the European Declaration of Human Rights into the declaration of European Human Rights. This would be to deny the same rights to other men. This would mean betraying the spirit of European civilisation' (Vasak 1963, p. 1208). This plea, however, proved to be in vain.

Ultimately, the ECHR formed a sort of trade-off compared with the UDHR. It broke new ground in creating a supranational court with the power to issue binding judgments. But this came at the expense of a broad conception of rights, as enshrined in the UDHR, as only civil and political rights made it into the Convention. As Duranti states, the adoption of the Convention

marked more than a momentous step forward in the genesis of international human rights law. It signified a rejection of the expansive understanding of human rights enshrined in the Universal Declaration and the emergence of a transnational conservative countercurrent to domestic policies implemented in recent years at the level of the nation-state. (Duranti 2016, p. 278)

\subsubsection{Thin Conceptions of Justice in the Formation of the European Economic Community}

Turning, now, to the institution that would one day become the European Union, the story of human rights is, in the words of de Búrca, one of 'the road not taken' (de Búrca 2011). There was a moment of opportunity, in 1952 and 1953, when there was a real chance that further European integration would be aimed at protecting human rights and democratic institutions. The European Movement, which a few years earlier had played such a crucial role in drafting the ECHR, set up the Comité d'études pour la Constitution 
européenne (CECE, Study Committee for the European Constitution), which was tasked with drafting a constitution for a European political community. The CECE's vision for a new European community was that it would guarantee 'the common well-being, existence and external security of the Member States and of protecting the constitutional order, democratic institutions and fundamental freedoms' (de Búrca 2011, p. 649). Subsequently, a draft Treaty on a European Political Community (EPC) was created, but this was discarded when the French National Assembly refused to ratify the European Defence Community (EDC) Treaty. Further European integration would be based on economic, rather than explicitly justice-based interests, starting with the European Coal and Steel Community in 1954. What is more, in contrast with the founding of the Council of Europe, European economic integration would be more state-driven and technocratic (Duranti 2016).

Justice conceptions at the European level became very thin, apart from two powerful ideas. The first was that economic cooperation would preserve peace, especially between Germany and France. This was famously put forward in the Schuman Declaration of May 1950, proposing the creation of a European Coal and Steel Community. The second underlying justice conception, also already mentioned in the Schuman Declaration, was linked to the idea that economic cooperation would raise the standard of living. The resolution adopted at the Messina Conference (June 1955), which laid the groundwork for the future EEC, reiterated this and stated that a policy of further European integration 'appears ... to be indispensable if Europe's position in the world is to be maintained, her influence restored, and the standard of living of her population progressively raised' ${ }^{1}$ Apart from this, however, there is little evidence of any justice concerns in the resolution at all.

The Treaty of Rome, establishing the EEC in 1957, contained Four Freedoms of a very different nature from those formulated by Roosevelt. These were the Four Freedoms of the internal market; of movement of goods, capital, services and workers. The Treaty contained no reference to human rights, with the exception of a provision on equal pay for men and women (Article 119). The EEC was premised on the idea that the Member States had strong national welfare systems in place, and that social policy at the European level could be minimal. The Treaty did contain a chapter on social policy (Articles 117-128), but the founding fathers agreed that the creation of the common market would not require harmonization of labour and social standards; this was the notion of 'embedded liberalism' (Ashiagbor 2013). Domestic social policies would ensure that the fruits of European economic cooperation would be distributed fairly within each state, in line with national preferences (Vandenbroucke 2017). The important exception to this was agriculture, as the Treaty of Rome provided that a common agricultural policy would be established 'to ensure thereby a fair standard of living for the agricultural population, particularly 
by the increasing of the individual earnings of persons engaged in agriculture' (Article 39(1)b). Thus, Europe was sometimes called a welfare state for farmers (Knudsen 2009).

The underlying idea was that European economic cooperation would bring what later scholars have termed 'upward convergence' (Vandenbroucke 2017, p. 22). The standard of life would improve everywhere in Europe, but the poorer countries would develop faster than the richer ones, thus reducing differences between them over time. In justice terms, the idea of upward convergence mostly translates to distributive justice rather than redistributive justice. The newly created EEC was not constitutionally committed to the redistribution of wealth, but the upward convergence idea can nevertheless be connected to an egalitarian ideal, namely that equality should be promoted by 'levelling up' rather than 'levelling down' (which would mean reaching equality at the level of the lowest common denominator, making everybody equally badly off) (Fredman 2011).

Eventually, the overarching aim of the Community was laid out in Article 2:

The Community shall have as its task, by establishing a common market and progressively approximating the economic policies of Member States, to promote throughout the Community a harmonious development of economic activities, a continuous and balanced expansion, an increase in stability, an accelerated raising of the standard of living and closer relations between the States belonging to it. (Article 2)

The references to harmony and stability point to a conception of justice as peace, and the reference to the standard of living hints at justice as prosperity, but there is not much else. Kochenov's view is that, in later years, '[t]he grand promise of European integration ended up being hijacked, if not consumed by the Internal Market' (Kochenov et al. 2015, p. 27). Though this view might not be shared by everyone, it is clear that this foundational document took what would one day become the European Union away from the wide variety of justice conceptions present in earlier years, to a much narrower interpretation.

\subsection{CONCEPTIONS OF JUSTICE}

What, now, in very general terms, can be considered the conceptions of justice that underpinned the early days of European integration? In previous sections, we analysed the understandings of justice as they emerged in day to day encounters in the key moments described above, as well as in key texts. Here, it is clear how such conceptions shifted over time, shaped not only by the geo-political context but also by individuals and the coalitions that they formed. In all, there were clearly conceptions of justice that conquered and 
were thus codified in legal text, others that remained deeply contested and others that were more or less circumvented.

\subsubsection{Conceptions that Conquered}

If there was one understanding of justice, one overarching objective shared by all negotiators in the period analysed, it was that of justice as peace. Roosevelt's emphasis on the 'Freedom from Fear' for everyone in the world pointed at the simple need for an absence of warfare, but also for disarmament and international cooperation towards that overarching objective. The first article of the UN Charter defines maintaining international peace and security as the first purpose of the UN, with other goals subservient to that end. At the Congress of Europe, Churchill quoted freedom from fear as the main objective of European integration. The ECHR emphasizes that fundamental freedoms are the 'foundation of justice and peace' (ECHR, 1950, preamble), and the Treaty of Rome underlines that economic and social progress, and eliminating trade barriers would ultimately 'strengthen peace and liberty' (Treaty of Rome, 1957, preamble). Peace, in all instances, is the overarching objective.

Another outcome of the negotiations, much less logical to many, was the understanding of justice as liberal freedoms. The 'Freedom of every person to worship God in his own way' and the 'freedom of speech and expression' (Roosevelt 1941) that FDR formulated as what was essentially at stake in war also became key objectives of peacetime cooperation. Whereas the UDHR still included a much broader understanding of rights and freedoms, the ECHR exclusively codified these civil and political rights. Such freedoms were combined with an emphasis on the free market, an approach already apparent during the Congress of Europe of 1948 and later codified in the EEC.

In terms of the institutional architecture needed to guarantee both peace and these particular freedoms it was supranationalism that proved victorious. Such supranationalism went much further than the mere intergovernmental cooperation of the UN. It included the commitment, of the nations that founded the Council of Europe, to give up part of their sovereignty to strengthen the rule of law at a European level. The ECtHR, after all, was given the mandate to control whether states complied with their human rights obligations. In these choices one discerns a concept of justice as working together, with the movement 'towards an ever-closer union' as a manifestation of justice in itself.

\subsubsection{Conceptions Contested}

The justice contestations in post-war Europe saw clear winners. Other concepts, sidelined in the process, were only to emerge much later. Most notably, this applies to the understanding encapsulated in FDR's 'Freedom from Want', 
which could roughly be translated as redistributive justice, with social and economic rights as key stepping stones towards this aim. Such an internationalization of the American New Deal was still an option at the start of the negotiations on the UN and the UDHR. The Congress of Europe, however, proved to be a key moment in sidelining social and economic rights, which subsequently were conspicuously absent from the ECHR. The Congress of Europe did deal with social and economic questions in its Social and Economic Committee, but the soon to be formed Council of Europe did not have jurisdiction on these matters. With the bifurcation of the European project into the Council of Europe and the European Economic Communities, and with the exclusion of social and economic rights from the ECHR, questions of distributive justice thus became mainly the province of the EEC. However, while the EEC was based on the ideal of upwards convergence, apart from in the field of agriculture, there was little by way of actual redistribution of wealth and resources. The Marshall Plan left aside, founders of the European institutions relied on strong national welfare states, reliant on national welfarism, not on European integration, to bring about redistributive justice.

Justice as representation was also sidelined. What was at stake here was who would get to participate, in what manner, in the newly shaped European polity. The groundswell movement for such a polity, clearly, consisted of individuals and civil society. They provided the philosophical grounding, wrote the pamphlets, organized the meetings and public support. They also ensured that 'human rights' made it as an objective of the UN. In addition, they arduously pleaded for a democratic European parliament. In the end, however, such public participation in the European project would be marginalized, with both the Council of Europe and - even more - the EEC as intergovernmental entities.

A third conception of justice for which the seed was planted in the post-war era, but which would remain in the freezer for half a century afterwards, was that of justice as accountability. Nuremberg came to stand for an ideal closely related to natural law, the notion that there are certain crimes so heinous that they shock the conscience of mankind, and thus deserve prosecution by the international community - whatever the laws of the land. This understanding of justice made it to the Genocide Convention, but its actual institutional consequence - the setting up of a permanent international criminal court to prosecute the crimes concerned - was not taken any further as the Cold War set in.

\subsubsection{Conceptions Circumvented}

For all the openness in the post-war period, Spinelli's 'molten matter' saw very little attention with regard to a number of understandings of justice which a modern-day spectator may consider key. For one, FDR's 'everywhere in the 
world' would largely prove to be a hollow phrase. The idea of universal justice for all mankind might have been rhetorically present in negotiations on the UDHR, but the millions of people in European colonies, under colonial rule, were quickly exempted from the justice codified in the post-war period. This is not only apparent in the way in which FDR's idea of self-determination, for countries large and small, disappeared from the table. It also shows in the lack of regard for the rights enshrined in the European Convention in the wars fought by many European countries against independence movements in their colonies, and in the inclusion of the 'colonial clause' in the text of the Convention itself. Clearly, the subject of European justice conceptions, in the eyes of the founders, lived on continental Europe.

Finally, it is striking to what degree justice as recognition of minority rights and the rights of vulnerable persons was absent in post-war discussions. The protection of minorities was a central object of international cooperation in the interbellum, and direly needed in the period after the Second World War. Still, there was very little attempt to codify the protection of those groups that suffered most from discrimination because of their position as a group. One reason could be the way in which the explicit attention for particular groups had led to the atrocities of the Second World War. Another, more political, could be that the lobbying position of minorities as such was not as strong as that of other groups.

\subsection{CONCLUSION}

This chapter has emphasized the degree to which the codification of justice in Europe was the outcome of the work of individuals, at a particular moment in time, against the background of geo-political forces. One of these individuals, Hendrik Brugmans, by 1958 labelled the Congress of Europe 'a tepid affair' (Brugmans 1969, p. 25). By then, the inspiration in FDR's Four Freedoms speech and the passion clearly present at the Congress of Europe had worn out, and given way to technocratic and pragmatic cooperation around a specific conception of justice. If justice is understood as 'a set of practices and procedures developed from our responses to injury and wrongdoing, a notion born of experiences - of sympathy, compassion, pain, suffering and outrage' (Douglas-Scott 2015, p. 63), it is clear to what degree both the wartime experience and that of subsequent events shaped initial institutional responses and debates. It was the assault on peace that led to its prioritization, the abuse of power by the nation-state that led to its curtailment in the form of human rights and supranationalism, and the fear of communism that led to the emphasis on liberal and political rights. Also, European justice was - though less explicitly - formulated against the claims to universality and self-determination that many people in the colonies, under European rule, stood for. 
As such, justice as it was conceived, debated, negotiated and ultimately institutionalized in post-war Europe can be understood as a movement from 'four to fewer freedoms'. As contributions by Safradin and De Vries (Chapter 7), Anderson (Chapter 8) and Knijn and Hiah (Chapter 10) to this volume set out, these institutionalized conceptions still cast their shadow over Europe today. The 'contested' and the 'circumvented' conceptions of justice discussed above (justice as redistribution, representation, accountability, universality, and the recognition of minorities) have remained salient, or have become even more salient over time. The narrow understanding of justice as human rights in general, and liberal and political rights in particular, has led to the criticism that attention is lacking to social and economic rights, and to social and economic justice in the broader sense. The lack of accountability for large-scale violence continues to impact feelings of (in)justice in Europe. One of the other key critiques of European supranational institutions today, concerning the lack of democratic legitimacy, can also be related to conceptions of justice as participation and representation sidelined in those early days.

Finally, the lack of attention for equality, and for the needs of minorities, both within Europe and globally, remains one of the most pressing justice concerns. However, ideas that were once merely trickles, feeding into the river of justice in Europe, could be strengthened again in the future. If justice, as institutionalized and codified, was the work of men in their times, it is also possible for people who are concerned about the course it took to renegotiate its contents in this particular day and age.

\section{NOTE}

1. Resolution adopted by the Ministers of Foreign Affairs of the Member States of the E.C.S.C. at their meeting at Messina (1-3 June 1955).

\section{REFERENCES}

Ashiagbor, Diamond (2013), 'Unravelling the embedded liberal bargain: Labour and social welfare law in the context of EU market integration', European Law Journal, 19 (3), 303-24.

Atlantic Charter (1941), 'The Atlantic Charter': Declaration of Principles issued by the President of the United States and the Prime Minister of the United Kingdom, 14 August 1941, accessed 23 April 2020 at https://www.nato.int/cps/en/natohq/official texts $16912 . \mathrm{htm}$.

Bates, E $\bar{d}$ (ed.) (2010), The Evolution of the European Convention on Human Rights: From Its Inception to the Creation of a Permanent Court of Human Rights, Oxford: Oxford University Press.

Borgwardt, Elizabeth (2007), A New Deal for the World, Boston, MA: Harvard University Press. 
Briand, Aristide (1930), 'Memorandum on the organization of a regime of European Federal Union', Series of the League of Nations Publications, VII (4), pp. 9-14.

Brugmans, Hendrik (ed.) (1969), Le congrès de La Haye - avant, pendant et après, in European Yearbook, Vol. XV, published under the auspices of the Council of Europe, La Haye and The Hague: Martinus Nijhoff, pp. 1-13.

Búrca, Gráinne de (2011), 'The road not taken: The European Union as a global human rights actor', American Journal of Comparative Law, 105 (4), 649-93.

Chakrabarty, Dipesh (ed.) (2009), Provincializing Europe: Postcolonial Thought and Historical Difference, Princeton, NJ: Princeton University Press.

Churchill, Winston (1941), Speech of 9 September 1941, accessed 3 March 2020 at http://hansard.millbanksystems.com/.

Churchill, Winston (1946a), 'The Sinews of Peace', speech held at Westminister College, Fulton, Missouri, 5 March 1946, accessed 23 April 2020 at https:// winstonchurchill.org/resources/speeches/1946-1963-elder-statesman/the-sinews-of -peace/.

Churchill, Winston (1946b), Speech delivered at the University of Zurich, 19 September 1946, accessed 23 April 2020 at https://rm.coe.int/16806981f3.

Churchill, Winston (1948), Address given at the Hague Congress, 7 May 1948, accessed 23 April 2020 at https://www.cvce.eu/content/publication/1999/1/1/58118da1-af22 -48c0-bc88-93cda974f42c/publishable_en.pdf.

Cohen, Antonin (2009), 'Une conception nouvelle du parlementarisme? Différenciations sociales et clivages politiques à la Haye et au-delà', in Jean-Michel Guieu and Christophe Le Dréau (eds), Le 'Congrès de l'Europe' à la Haye (1948-2008), Bruxelles: Peter Lang, pp. 273-86.

Dinan, Desmond (ed.) (2004), Europe Recast: A History of European Union, Basingstoke: Palgrave Macmillan.

Douglas-Scott, Sionaidh (2015), 'Justice, injustice and the rule of law in the EU', in Dimitry Kochenov, Gráinne de Búrca and Andrew Williams (eds), Europe's Justice Deficit? Oxford: Hart Publishing, pp. 51-66.

Duranti, Marco (2016), The Conservative Human Rights Revolution: European Identity, Transnational Politics, and the Origins of the European Convention, Oxford: Oxford University Press.

Ead, Lisa (2016), 'Freedom of speech', in Jeffrey A. Engel (ed.), The Four Freedoms: Franklin D. Roosevelt and the Evolution of an American Idea, Oxford: Oxford University Press, pp. 39-72.

ECHR, Convention for the Protection of Human Rights and Fundamental Freedoms, Rome, 4 November 1950.

Engel, Jeffrey A. (2016), The Four Freedoms: Franklin D. Roosevelt and the Evolution of an American Idea, Oxford: Oxford University Press.

European Movement (1949), Europe Unites: The Hague Congress and After, London: Hollis and Carter.

Fredman, Sandra (2011), Discrimination Law, Oxford: Oxford University Press.

Glasius, Marlies (2006), The International Criminal Court: A Global Civil Society Achievement, Oxford: Routledge.

Glendon, Mary Ann (2002), A World Made New: Eleanor Roosevelt and the Universal Declaration of Human Rights, New York: Random House.

Hoopes, Townsend and Douglas Brinkley (1997), FDR and the Creation of the U.N., New Haven, CT: Yale University Press. 
Humphrey, John P. (1968), 'The United Nations Sub-Commission on the Prevention of Discrimination and the Protection of Minorities', The American Journal of International Law, 62 (4), 869-88.

Kochenov, Dimitry, Gráinne de Búrca and Andrew Williams (eds) (2015), Europe's Justice Deficit? Oxford: Hart Publishing.

Korey, William (2001), NGOs and the Universal Declaration of Human Rights: A Curious Grapevine, New York: Springer.

Knudsen, Ann-Christina (ed.) (2009), Farmers on Welfare: The Making of Europe's Common Agricultural Policy, New York: Cornell University Press.

Loth, Wilfried (2015), Building Europe: A History of European Unification, Berlin: Walter de Gruyter.

Maritain, Jacques (1948), 'Introduction', in Human Rights: Comments and Interpretations, A Symposium edited by UNESCO, London: Allan Wingate, p. 16.

Morsink, Johannes (1999), The Universal Declaration of Human Rights: Origins, Drafting, and Intent, Philadelphia, PA: University of Pennsylvania Press.

Norman, Roger and Sarah Zaidi (2008), Human Rights at the UN: The Political History of Universal Justice, Bloomington and Indianapolis, IN: Indiana University Press.

Robertson, Arthur Henry (1961), The Council of Europe: Its Structure, Functions and Achievements, London: Stevens \& Sons.

Roosevelt, Franklin D. (1941), 'The Annual Message to Congress', 6 January 1941, accessed 23 April 2020 at https://www.ourdocuments.gov/doc.php?flash=false\&doc $=70$ \&page $=$ transcript.

Roosevelt, Franklin D. (1951), My Own Story; From Private and Public Papers, Boston: Little, Brown and Company.

Sands, Philippe (2003), From Nuremberg to The Hague: The Future of International Criminal Justice, Cambridge: Cambridge University Press.

Scharf, Michael P. (2010), 'Seizing the Grotian moment: Accelerated formation of customary international law in times of fundamental change', Cornell International Law Journal, 43 (3), 439-69.

Spinelli, Altiero and Ernesto Rossi (1941), 'The Ventotene Manifesto', available at https://www.federalists.eu/uef/library/books/the-ventotene-manifesto/.

Treaty of Rome (1957), Treaty establishing the European Economic Community, 1957, available at https://eur-lex.europa.eu/legal-content/EN/TXT/?uri=LEGISSUM $\% 3$ Axy0023.

Vandenbroucke, Frank (2017), 'The idea of a European social union: A normative introduction', in Frank Vandenbroucke, Catherine Barnard and Geert De Baere (eds), A European Social Union after the Crisis, Cambridge: Cambridge University Press, pp. 3-46.

Vasak, Karl (1963), 'The European Convention of Human Rights beyond the frontiers of Europe', International and Comparative Law Quarterly, 12 (4), 1206-31.

Ward, Ian (2003), 'A decade of Europe? Some reflections on an aspiration', Journal of Law and Society, 30 (2), 257.

Williams, Andrew (2010), The Ethos of Europe: Values, Law and Justice in the EU, Cambridge: Cambridge University Press. 